\title{
Effect of REG I $\alpha$ protein on angiogenesis in gastric cancer tissues
}

\author{
KEN HARA $^{1}$, HIROKAZU FUKUI ${ }^{1}$, CHAO SUN $^{1}$, YOSHITAKA KITAYAMA ${ }^{1}$, HIROTSUGU EDA ${ }^{1}$, \\ TAKAHISA YAMASAKI ${ }^{1}$, TAKASHI KONDO ${ }^{1}$, TOSHIHIKO TOMITA ${ }^{1}$, TADAYUKI OSHIMA ${ }^{1}$, \\ JIRO WATARI $^{1}$, TAKAHIRO FUJIMORI ${ }^{2}$ and HIROTO MIWA ${ }^{1}$ \\ ${ }^{1}$ Division of Gastroenterology, Department of Internal Medicine, Hyogo College of Medicine, Nishinomiya; \\ ${ }^{2}$ Department of Surgical and Molecular Pathology, Dokkyo University School of Medicine, Tochigi, Japan
}

Received December 31, 2014; Accepted February 10, 2015

DOI: $10.3892 /$ or.2015.3878

\begin{abstract}
Regenerating gene (REG) I $\alpha$ is not only overexpressed in a subset of gastric cancers, but also involved in tumor progression. However, the mechanism by which (REG) I $\alpha$ promotes tumor growth is not fully understood. In the present study, we investigated whether REG I $\alpha$ plays a role in angiogenesis during the progression of gastric cancers. Expression of REG I $\alpha$ and its receptor (EXTL3; exostoses like-3) was examined using immunohistochemistry in specimens of human gastric cancer. Microvessel density (MVD) in gastric cancer tissues was evaluated using an image analysis system after CD34 immunostaining. Relationships among clinicopathological features, REG I $\alpha$ expression and MVD in gastric cancer tissues were analyzed. Effects of REG I $\alpha$ protein on HUVEC cells in terms of proliferation and anti-apoptosis were assessed by WST-1 assay and FACS, respectively. Furthermore, the intracellular signaling by which REG I $\alpha$ exerts its biological roles was examined in vitro. REG I $\alpha$ expression was significantly related to lymph node metastasis and its receptor EXTL3 was ubiquitously expressed in not only the tumor cells, but also the tumor vessel cells in the gastric cancer tissues. MVD was significantly higher in gastric cancers that were REG I $\alpha$-positive than in those that were negative. Treatment with REG I $\alpha$ protein promoted growth and anti-apoptosis through activation of the ERK and Akt signaling pathways in HUVEC cells, whereas these effects
\end{abstract}

Correspondence to: Dr Hirokazu Fukui, Division of Gastroenterology, Department of Internal Medicine, Hyogo College of Medicine, 1-1, Mukogawa, Nishinomiya, Hyogo 663-8501, Japan

E-mail:hfukui@hyo-med.ac.jp

Abbreviations: REG, regenerating gene; EXTL3, exostoses like-3; MVD, microvessel density; HUVEC, human umbilical vein endothelial cell; ERK, extracellular signal-regulated protein kinase; PI, propidium iodide; FITC, fluorescein isothiocyanate; FACS, fluorescence activated cell sorting; $\mathrm{CD}$, cluster of differentiation

Key words: REG protein, gastric cancer, angiogenesis, EXTL3, microvessel were attenuated by treatment with anti-REG I $\alpha$ antibody. REG I $\alpha$ protein may play a role in angiogenesis during progression of gastric cancer.

\section{Introduction}

The regenerating gene (Reg) was originally isolated from a complementary DNA library of rat regenerating pancreatic islets (1). Thereafter, its human homologue REG I $\alpha$ was suggested to be involved in the pathophysiology of not only the gastrointestinal inflammation but also its associated cancer (2-4). Moreover, we previously clarified that REG I $\alpha$ protein acts as a trophic and/or anti-apoptotic factor in the development of gastric cancer (5). With regard to the clinical significance of REG I $\alpha$ expression, it has been reported that REG I $\alpha$ is a useful marker for predicting the response to chemotherapy or prognosis in patients with gastric cancer (6-8).

Gastric cancer has a poor prognosis because of its marked propensity for invasion and metastasis. Gastric cancer tissues are composed of not only cancer cells but also stromal cells, and their interaction is thought to be crucial for tumor progression. Regarding the role of REG I $\alpha$ protein, accumulating evidence suggests that the REG I $\alpha$ receptor (EXTL3; exostoses like-3) is ubiquitously expressed in gastric cancer cells (9) and that REG I $\alpha$ protein secreted from the cells promotes tumor cell growth or survival through an autocrine or paracrine mechanism (5). However, the effect of REG I $\alpha$ protein on stromal cells remains unclear. Endothelial cells, which are an important stromal component in the tumor microenvironment, play a role in angiogenesis by interacting with the tumor cells, resulting in tumor progression (10). Therefore, in the present study, we investigated whether REG I $\alpha$ protein promotes the growth and survival of the endothelial cells and examined the intracellular signaling by which REG I $\alpha$ protein affects endothelial cell growth and survival. Moreover, to clarify the significance of REG I $\alpha$ protein in angiogenesis, we investigated the expression of REG I $\alpha$ and microvessel density (MVD) in gastric cancer tissues.

\section{Materials and methods}

Reagents and cell culture. Anti-Akt, anti-phospho-specific Akt (p-Akt; Ser473), anti-ERK, and anti-phospho-specific ERK (p-ERK) antibodies were purchased from Cell Signaling 
Technology (Beverly, MA, USA). Anti- $\beta$-actin antibody was purchased from Sigma.

The human umbilical vein endothelial cells (HUVECs) were obtained from Lonza (Walkersville, MD, USA) and maintained in EGM-2 medium containing the bullet kit according to the supplier's instructions. All the cells were incubated at $37^{\circ} \mathrm{C}$ in a humidified atmosphere of $5 \% \mathrm{CO}_{2}$.

Recombinant REG I $\alpha$ protein was generated in insect cells using the Bac-to-Bac expression system (Invitrogen, Carlsbad, CA, USA) by Kitayama Labes (Ina, Japan). Full length human REG I $\alpha$ cDNA was cloned and inserted into the pFastBac vector (Invitrogen). The constructed vector was then transformed into E. coli $\mathrm{DH} 10 \mathrm{Bac}$, and recombinant Bacmid-REG I $\alpha$ was produced by transposition. Then, Spodoptera frugiperda (Sf9) insect cells were infected with Bacmid-REG I $\alpha$ to generate the recombinant baculoviruses carrying human REG I $\alpha$ cDNA. The recombinant baculovirus particles were harvested in the culture supernatant, and used to infect $S f 9$ insect cells in a large volume $(1 \mathrm{~L})$ of culture medium. The supernatant (crude extract) including the secreted REG I $\alpha$ protein was then incubated with Ni-NTA agarose (Qiagen) and purified by elution through SP-Sepharose (GE Healthcare Life Science).

RNA extraction and reverse transcription-polymerase chain reaction (RT-PCR). Total RNA was extracted from each cell line using Trizol reagent (Invitrogen). Five micrograms of total RNA were reverse-transcribed using oligo dT primer (Applied Biosystems, Branchburg, NJ, USA) and $200 \mathrm{U}$ of Superscript $^{\mathrm{TM}}$ II reverse transcriptase (Invitrogen) in a total volume of $20 \mu 1$. For the following PCR, pairs of oligonucleotide primers for human EXTL3 (11) and human glyceraldehyde3-phosphate dehydrogenase (GAPDH) (9) were prepared. Human EXTL3: 5'-CAACCGATTCTTACCCTGG-3' (sense) and 5'-GGAAGTTCATGGCAATGTCC-3' (antisense); human GAPDH: 5'-GGCTGCTTTTAACTCTGGTA-3' (sense and 5'-ATGCCAGTGAGCTTCCCGT-3' (antisense). One microliter of RT product (cDNA) was amplified by PCR as previously described (11).

Western blot analysis. Following treatment with or without a reagent, the cells were lysed in protein extraction buffer as previously reported (12). Protein extract $(25 \mu \mathrm{g})$ was fractionated by sodium dodecyl sulfate polyacrylamide gel electrophoresis and transferred to a polyvinylidene difluoride membrane. The membrane was incubated with a primary antibody and then with a peroxidase-conjugated secondary antibody. Proteins were detected using an enhanced chemiluminescence system (Amersham Biosciences, Buckinghamshire, UK).

Tissue specimens and histological examination. A total of 31 gastric cancer tissues was obtained from specimens that were resected surgically at Dokkyo University School of Medicine. The tissue specimens were fixed in a $10 \%$ formalin solution and embedded in paraffin. This study was approved by the Dokkyo University Surgical Pathology Committee and an informed consent was obtained from all the participant patients.

Multiple hematoxylin and eosin-stained sections of all 31 lesions were examined (Table I). The following factors were determined for all the patients and lesions; age, sex, tumor
Table I. Clinicopathological features of the patients with gastric cancer.

Gender

$\begin{array}{llr} & \text { Man } & 22(71.0 \%) \\ & \text { Woman } & 9(29.0 \%) \\ \text { Age }(y r, \text { mean } \pm \text { SE) } & & 65.8 \pm 1.7 \\ \text { Tumor location } & & \\ & \text { Lower } & 7(22.6 \%) \\ & \text { Mid } & 12(38.7 \%) \\ & \text { Upper } & 12(38.7 \%)\end{array}$

Lauren's classification

$\begin{array}{lr}\text { Intestinal type } & 9(29.0 \%) \\ \text { Diffuse type } & 22(71.0 \%)\end{array}$

Stage

$\begin{array}{lr}\text { I } & 5(16.1 \%) \\ \text { II } & 3(9.7 \%) \\ \text { III } & 12(38.7 \%) \\ \text { IV } & 11(35.5 \%)\end{array}$

Lymphatic invasion

$\begin{array}{lr}\text { None } & 1(3.2 \%) \\ \text { Present } & 30(96.8 \%)\end{array}$

Venous invasion

$\begin{array}{lr}\text { None } & 4(12.9 \%) \\ \text { Present } & 27(87.1 \%)\end{array}$

Lymph node metastasis

$\begin{array}{lr}\text { None } & 5(16.1 \%) \\ \text { Present } & 26(83.9 \%)\end{array}$

size, tumor location, Lauren's histological classification, tumor invasion, lymph node metastases and tumor stage according to the system of the American Joint Committee on Cancer.

Immunohistochemistry. Immunohistochemical staining for CD34 and REG I $\alpha$ was performed with an Envision kit (DAKO, Kyoto, Japan) as described previously $(3,13)$, using anti-CD34 antibody (1:200; Santa Cruz Biotechnology, Santa Cruz, CA, Japan) and anti-REG I $\alpha$ antibody (1:500). Finally, the sections were incubated in 3,3'-diaminobenzide tetrahydrochloride with $0.05 \% \mathrm{H}_{2} \mathrm{O}_{2}$ for 3 min and then counterstained with Mayer's hematoxylin. To evaluate the immunoreactivity of REG I $\alpha$ protein, at least 500 tumor cells were counted in five different visual fields for each sample of the cancerous tissues. A specimen was considered positive for REG I $\alpha$ protein if $20 \%$ of the tumor cells were positively stained (9). To evaluate angiogenesis in the tumors, MVD was assessed by immunostaining with the anti-CD34 antibody as described above. Five different fields (x200) were digitally photographed with a highresolution microscope (DP20, Olympus, Tokyo, Japan), and the obtained images were analyzed using NIH ImageJ1.47 image analysis software (http://rsbweb.nih.gov/ij). MVD was quantified as the percentage of the microvascular area relative to the tumor stroma in each image and the results were averaged (14).

Cell growth and apoptosis assay. HUVECs were seeded in complete medium in 96 -well plates $\left(1 \times 10^{4}\right.$ cells/well $)$ and 6-well 

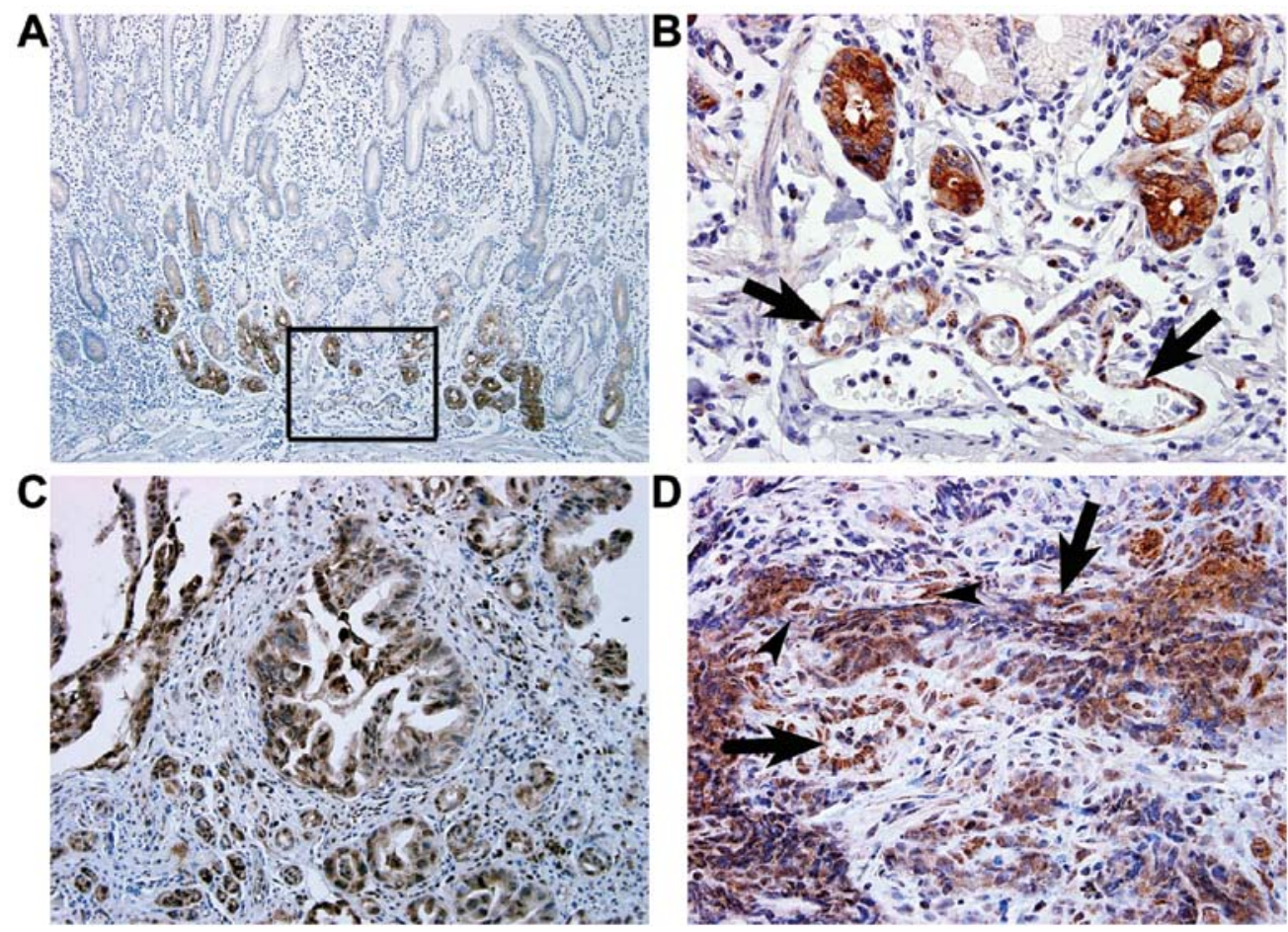

$\mathbf{E}$

Marker

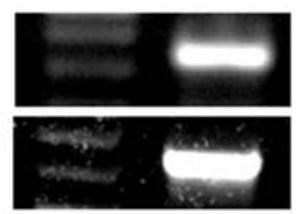

EXTL3

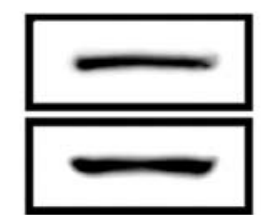

EXTL3

GAPDH

$\beta$-actin

Figure 1. Expression of EXTL3 (REG I $\alpha$ receptor) in the epithelium (A) and endothelial cells (B) in normal gastric mucosa. (A) EXTL3 is expressed strongly in the basal and weakly in the middle part in the gastric epithelium. (B) Magnified view of the square in (A). Arrows indicate the expression of EXTL3 in the endothelial cells. (C and D) Expression of EXTL3 in gastric cancer tissues. (C) Well-differentiated adenocarcinoma. (D) Poorly-differentiated adenocarcinoma. EXTL3 is expressed in tumor vessel cells (arrowheads) and cancer cells showing capillary formation (arrows). (E) Detection of EXTL3 mRNA and its gene product in HUVEC cells by RT-PCR (left) and western blot analysis (right), respectively.

plates $\left(2 \times 10^{5}\right.$ cells/well) for cell growth and apoptosis assay, respectively. After $24 \mathrm{~h}$, the cells were washed in a serum-free medium and then incubated with or without REG I $\alpha$ protein for the indicated time. For the cell growth assay, the treated cells were incubated with Premix WST-1 reagent (Takara, Tokyo, Japan) for $1 \mathrm{~h}$ and the plates were read at 450 and $600 \mathrm{~nm}$ in a spectrophotometer (Molecular Devices, Sunnyvale, CA, USA). For the apoptosis assay, the treated cells were collected, washed with PBS, and incubated with Annexin V-FITC and propidium iodide (PI) in binding buffer in accordance with the manufacturer's protocol (MEBCYTO-Apoptosis Kit; MBL, Ina, Japan). The stained cells were analyzed on a FACScalibur flow cytometer (Becton-Dickinson, Franklin Lakes, NJ, USA) and the data obtained were analyzed using CellQuest software (Becton-Dickinson).

Statistical analysis. All values were expressed as the mean \pm SEM. The data for MVD were analyzed using unpaired two-tailed $t$-test. Chi-squared analyses were performed to determine the correlation between various pathological parameters and Fisher's exact test was also performed when necessary. P-values of $<0.05$ were considered to indicate statistical significance.

\section{Results}

Expression of EXTL3 and its gene product in the endothelial cells in normal gastric tissues and gastric cancer. EXTL3 was ubiquitously expressed not only in the epithelial cells, but also in the endothelial cells in the normal gastric mucosa (Fig. 1A and B). In gastric cancer tissues, EXTL3 was expressed in tumor vascular cells as well as cancer cells (Fig. 1C and D).

Before examining the effect of REG I $\alpha$ protein on the endothelial cells, we tested the expression of EXTL3 in HUVEC. Subsequently, we confirmed that expression of EXTL3 and its gene product was detectable in the cells by RT-PCR and western blot analysis (Fig. 1E), suggesting that HUVECs have the capability of responding to REG I $\alpha$ stimulation.

REG I $\alpha$ protein activates the phosphorylation of ERK and Akt in HUVEC cells. The effect of REG I $\alpha$ protein on intracellular signaling was investigated in the HUVEC cells. The expression of p-ERK and p-Akt was enhanced by REG I $\alpha$ stimulation (10-100 nM) (Fig. 2A). The expression of p-ERK peaked in the HUVEC cells at 15 min after REG I $\alpha$ stimulation, and that of p-Akt was enhanced from $15 \mathrm{~min}$ and sustained for 
A

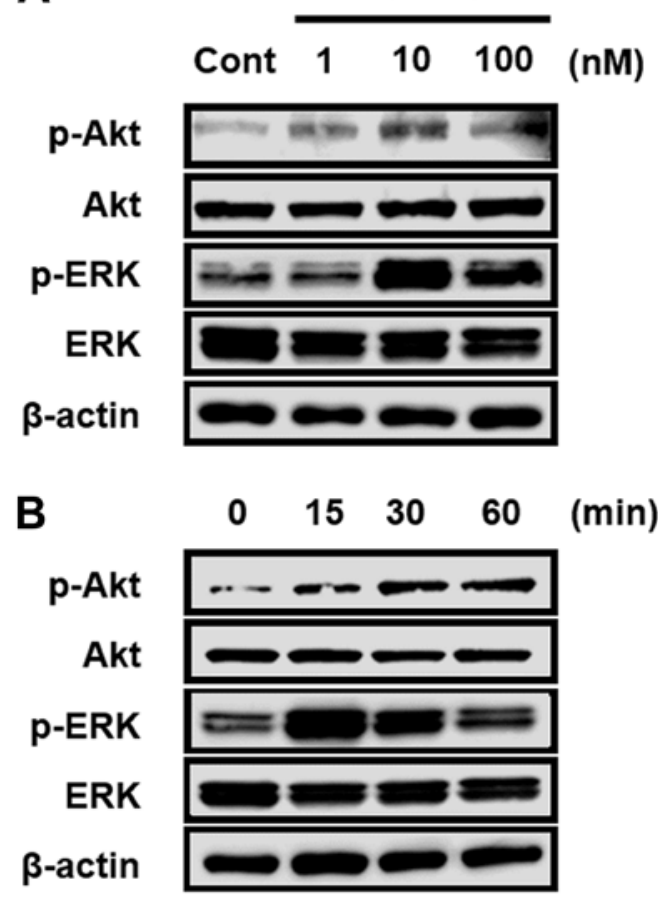

C

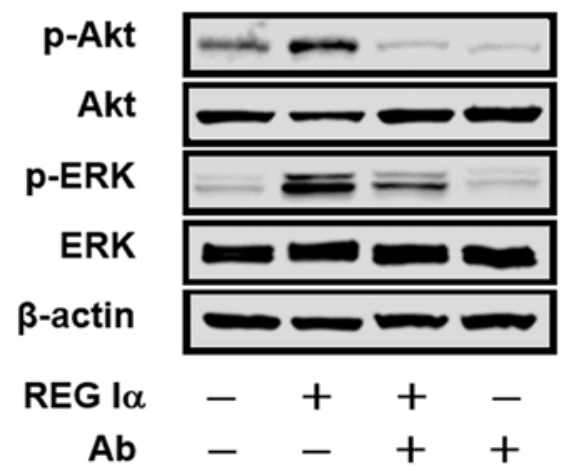

Figure 2. Effect of REG I $\alpha$ treatment on intracellular signaling in endothelial cells. (A) Dose-dependent effect of REG I $\alpha$ on phosphorylation of Akt and ERK in HUVEC cells. HUVEC cells $\left(2.5 \times 10^{5}\right)$ were cultured in $35-\mathrm{mm}$ dishes and treated with various concentrations of REG I $\alpha$ protein for $30 \mathrm{~min}$. Extracted protein was analyzed by western blot analysis, as described in Materials and methods. (B) Time course changes in Akt and ERK phosphorylation in HUVEC cells treated with REG I $\alpha$. HUVEC cells were similarly treated with REG I $\alpha$ protein $(10 \mathrm{nM})$ for the indicated times. (C) Effect of anti-REG I $\alpha$ antibody on REG I $\alpha$ protein-induced Akt and ERK phosphorylation in HUVEC cells. HUVEC cells were pretreated with anti-REG I $\alpha$ antibody ( $\mathrm{Ab} ; 50 \mu \mathrm{g} / \mathrm{ml}$ ) for $45 \mathrm{~min}$ and then stimulated with REG I $\alpha$ protein $(10 \mathrm{nM})$ for $30 \mathrm{~min}$.

60 min (Fig. 2B). We then examined whether anti-REG I $\alpha$ antibody inhibits the REG I $\alpha$-induced signaling in HUVEC cells. As shown in Fig. 2C, the basal level of p-ERK and p-Akt expression was decreased by treatment with REG I $\alpha$ antibody. Moreover, the increased expression of p-ERK and p-Akt in REG I $\alpha$-treated HUVEC cells was attenuated by concomitant administration of anti-REG I $\alpha$ antibody.

REG Ia protein promotes HUVEC cell growth and anti-apoptosis. To clarify the role of REG I $\alpha$ protein in angiogenesis, we examined the growth and anti-apoptosis effects of
REG I $\alpha$ protein on HUVEC cells in vitro. The rate of WST-1 cleavage was significantly and dose-dependently increased in REG I $\alpha$-treated HUVEC cells (Fig. 3A). Conversely, the increase in the level of WST-1 cleavage in REG I $\alpha$-treated cells was significantly reduced to almost the control level by addition of anti-REG I $\alpha$ antibody (Fig. 3B).

In control preparations, deprivation of growth factors in complete culture medium induced cell apoptosis and death. However, HUVEC cells treated with REG I $\alpha$ protein $(10 \mathrm{nM})$ showed significantly lower Annexin $\mathrm{V}$ positivity, than the control cells (Fig. 3C and D). Similarly, the percentage of PI-positive cells was significantly lower in the REG I $\alpha$-treated preparations than in the controls (Fig. 3C and D). On the other hand, the decrease of Annexin V or PI positivity in REG I $\alpha$-treated HUVEC cells was restored to the control level by concomitant administration of anti-REG I $\alpha$ antibody (Fig. 3D).

Relationship between REG I $\alpha$ expression and MVD in gastric cancer tissues. Among 31 samples of gastric cancer tissues, 19 (61.3\%) were positive for REG I $\alpha$ expression. Expression of REG I $\alpha$ was significantly associated with the prevalence of lymph node metastasis and tended to correlate with the tumor stage (Table II). MVD was significantly higher in gastric cancers at an advanced stage. In addition, MVD tended to be higher in gastric cancers with lymph node metastasis. Furthermore, we investigated the relationship between REG I $\alpha$ expression and MVD and observed that MVD was significantly higher in REG I $\alpha$-positive gastric cancers (Fig. 4).

\section{Discussion}

It has been reported that REG I $\alpha$ is overexpressed in various malignancies including cancers of the stomach $(3,6,9)$, colorectum (15), bile duct (16) and pancreas (17). Furthermore, microarray analyses have revealed that REG I $\alpha$ expression is markedly enhanced in gastric cancer tissues (18) and in fact we have previously shown that REG I $\alpha$ protein acts on gastric cancer cells as a growth and/or anti-apoptotic factor (5). Although the receptor for REG I $\alpha$ protein, which is identical to EXTL3, has been discovered fairly recently (19), its pathophysiological roles are poorly understood. In the present study using immunohistochemistry, we have demonstrated that EXTL3 is expressed in gastric cancer cells, in accordance with a previous study indicating that EXTL3 is ubiquitously expressed in gastric cancer cells in vitro (9), which would account for the observed effects of REG I $\alpha$ protein on gastric cancer cells. Interestingly, our immunohistochemical analysis also revealed that EXTL3 was expressed in tumor vessel cells and we confirmed the expression of EXTL3 in HUVEC cells in vitro. Thus, the present study indicates for the first time that REG I $\alpha$ protein may act on not only gastric cancer cells but also tumor vessel cells, which are an important component associated with tumor progression.

In a series of in vitro studies, we have investigated the possible role of REG I $\alpha$ on the human endothelial cells and have shown that REG I $\alpha$ protein promotes the proliferation of the endothelial cells. Furthermore, in the present study, we clarified that REG I $\alpha$ protein has an anti-apoptotic effect on the endothelial cells. Thus, REG I $\alpha$ protein appears to act on 
Table II. Relationship between clinicopathological features and REG I $\alpha$ expression or MVD in patients with gastric cancer.

\begin{tabular}{|c|c|c|c|c|}
\hline & $\begin{array}{l}\text { Number of REG I } \alpha \text {-positive/ } \\
\text { total number of patients }\end{array}$ & P-value & MVD & P-value \\
\hline Tumor location & & 0.0575 & & NS \\
\hline Lower & $7 / 7(100 \%)$ & & $9.44 \pm 2.39$ & \\
\hline Mid & $6 / 12(50.0 \%)$ & & $8.87 \pm 2.03$ & \\
\hline Upper & $6 / 12(50.0 \%)$ & & $12.08 \pm 2.26$ & \\
\hline Lauren's classification & & 0.2181 & & 0.5414 \\
\hline Intestinal type & $4 / 9(44.4 \%)$ & & $8.99 \pm 2.46$ & \\
\hline Diffuse type & $15 / 22(68.2 \%)$ & & $10.75 \pm 1.52$ & \\
\hline Stage & & 0.1088 & & 0.0459 \\
\hline $\mathrm{I} / \mathrm{II}$ & $3 / 8(37.5 \%)$ & & $5.94 \pm 1.39$ & \\
\hline III/IV & $16 / 23(69.6 \%)$ & & $11.74 \pm 1.55$ & \\
\hline Lymphatic invasion & & 0.2009 & & NS \\
\hline None & $0 / 1(0.0 \%)$ & & 9.78 & \\
\hline Present & $19 / 30(63.3 \%)$ & & $10.26 \pm 1.33$ & \\
\hline Venous invasion & & 0.6194 & & 0.730 \\
\hline None & $2 / 4(50.0 \%)$ & & $9.06 \pm 2.56$ & \\
\hline Present & $17 / 27(63.0 \%)$ & & $10.42 \pm 1.43$ & \\
\hline Lymph node metastasis & & 0.0385 & & 0.0614 \\
\hline None & $1 / 5(20.0 \%)$ & & $4.80 \pm 1.32$ & \\
\hline Present & $18 / 26(69.2 \%)$ & & $11.29 \pm 1.42$ & \\
\hline
\end{tabular}
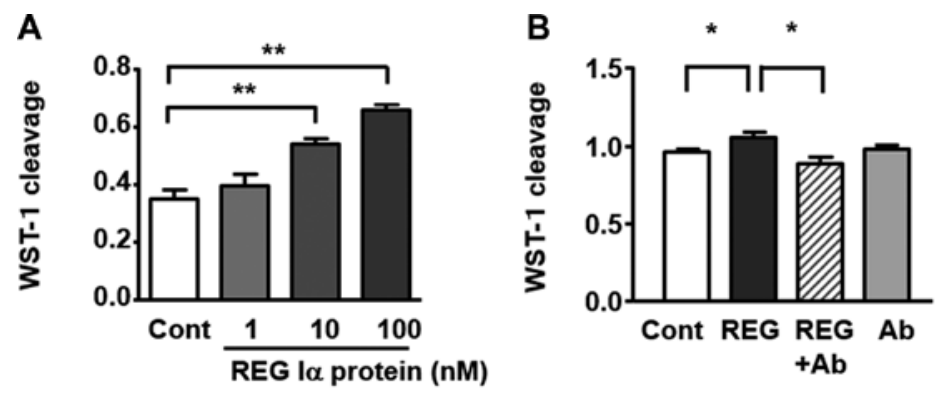

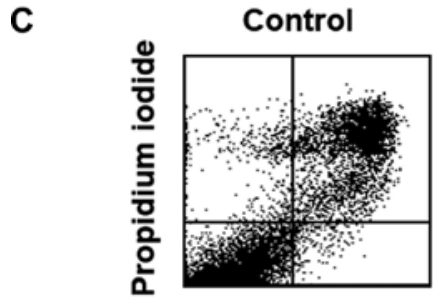

Annexin V

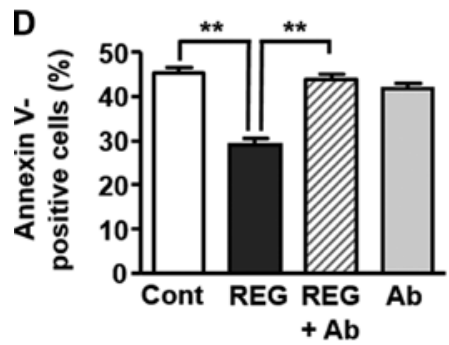

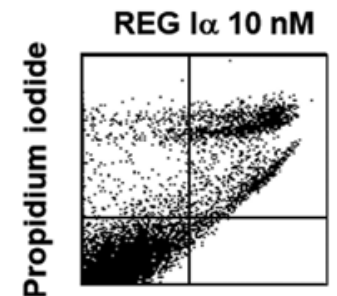

Annexin V

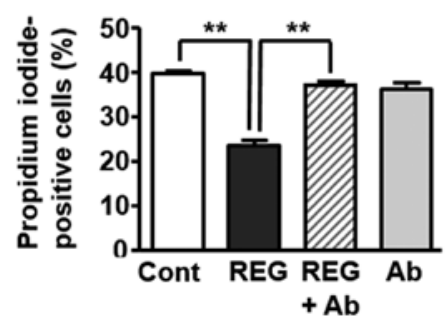

Figure 3. Effect of REG I $\alpha$ on growth (A and B) and apoptosis (C and D) of the endothelial cells. (A) The dose-dependent effect of REG I $\alpha$ on growth of the HUVEC cells. (B) Effect of anti-REG I $\alpha$ antibody (50 $\mu \mathrm{g} / \mathrm{ml}$ ) on HUVEC cell growth promoted by REG I $\alpha$ protein (10 $\mathrm{nM})$. (C) Representative graphs of FACS analysis using Annexin V-FITC and propidium iodide staining. HUVEC cells were treated with REG I $\alpha$ protein $(10 \mathrm{nM})$ and were evaluated as described in Materials and methods. (D) The effect of anti-REG I $\alpha$ antibody $(50 \mu \mathrm{g} / \mathrm{ml})$ on REG I $\alpha(10 \mathrm{nM})$-induced anti-apoptosis and survival of HUVEC cells. All the results are presented as the mean \pm SEM of four independent experiments. Significant differences between two groups at ${ }^{*} \mathrm{P}<0.05$ and ${ }^{* *} \mathrm{P}<0.01$. 


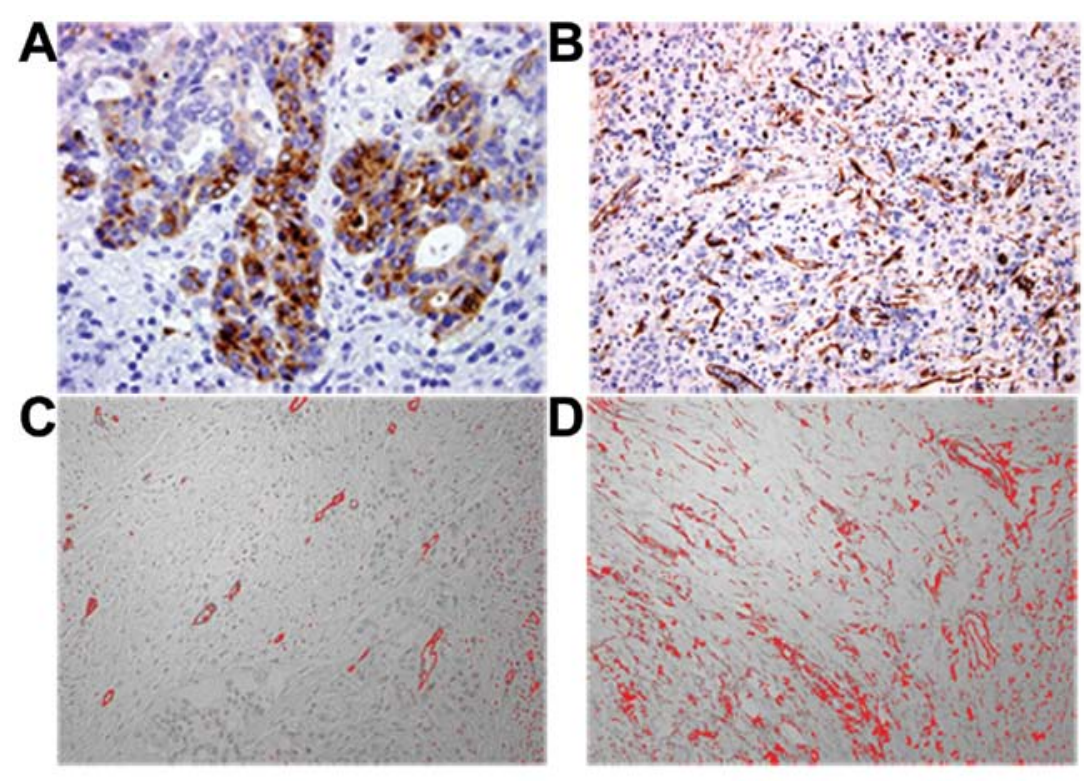

E

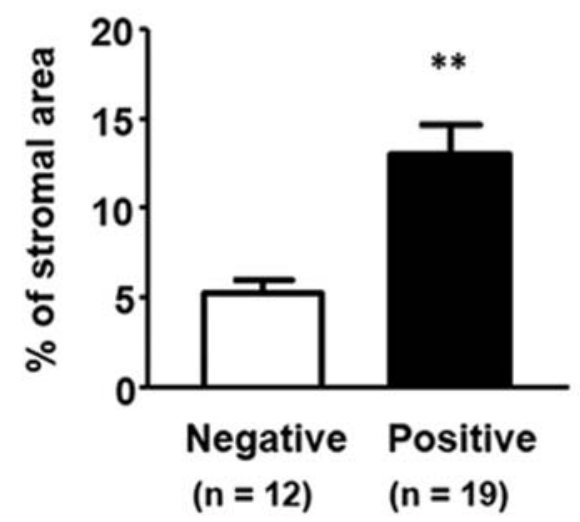

REG I $\alpha$ expression

Figure 4. Evaluation of REG I $\alpha$ expression and MVD in gastric cancer. (A and B) Immunostaining of REG I $\alpha$ and CD34 in gastric cancer tissue. (A) REG I $\alpha$ and (B) CD34 are expressed in tumor cells and tumor vessel cells, respectively. (C and D) Representative images showing microvascular areas (CD34; red) in (C) REG I $\alpha$-negative and (D) -positive gastric cancer. (E) Relationship between REG I $\alpha$ expression and MVD in gastric cancer tissues. ${ }^{* *}$ Significantly greater than in the REG I $\alpha$-negative preparation $(\mathrm{P}<0.01)$. MVD, microvessel density.

not only the gastric cancer cells (5), but also the endothelial cells as a growth and/or anti-apoptotic factor. In addition, to clarify how REG I $\alpha$ protein exerts its effects on endothelial cells, we examined the signaling pathways activated by REG I $\alpha$ protein in HUVEC cells. As shown in Fig. 2, REG I $\alpha$ stimulation enhanced the phosphorylation of ERK and Akt in HUVEC cells, similarly to stimulatory effect of REG I $\alpha$ protein on gastric cancer cells $(5,20)$. Conversely, treatment with anti-REG I $\alpha$ antibody attenuated the enhancement of ERK and Akt phosphorylation and simultaneously suppressed the growth-promoting and anti-apoptotic effects of REG I $\alpha$ on HUVEC cells. These findings suggest that REG I $\alpha$ protein acts on endothelial cells as a growth and/or anti-apoptotic factor via the ERK and Akt signaling pathways.

Angiogenesis is an important process associated with tumor progression. In this context, REG I $\alpha$ protein may promote tumor progression through its growth-promoting and/ or anti-apoptotic effect on the endothelial cells. To address this issue, we investigated the expression of REG I $\alpha$ and microvessel density in gastric cancer tissues. Clinicopathological analyses revealed that expression of REG I $\alpha$ was significantly associated with the prevalence of lymph node metastasis. Moreover, gastric cancers that were REG I $\alpha$-positive showed a significantly higher MVD than those that were negative. Although confirmation of these clinicopathological data may be necessary in a larger study, the present findings suggest that REG I $\alpha$ protein is indeed involved in gastric cancer angiogenesis. In addition, since receptors for REG I $\alpha$ protein are ubiquitously expressed not only in gastric cancer, but also in its endothelial cells, REG I $\alpha$ protein may contribute at least in part to tumor progression in REG I $\alpha$-positive gastric cancer.

In summary, we have shown that receptors for REG I $\alpha$ are expressed not only in tumor cells, but also tumor vessel cells in gastric cancer, and that angiogenesis is significantly promoted in gastric cancers that are REG I $\alpha$-positive. Moreover, we have clarified that REG I $\alpha$ protein exerts growth-promoting and anti-apoptotic effects on endothelial cells via ERK and Akt signaling. These findings suggest that REG I $\alpha$ protein plays an 
important role in angiogenesis during progression of gastric cancer.

\section{Acknowledgements}

We would like to thank Noriko Kamiya (Hyogo College of Medicine), Chiaki Matsuyama and Ayako Shimizu (Dokkyo University School of Medicine) for technical assistance. The present study was supported in part by Grants-in-aid for Scientific Research 26460953 from the Ministry of Education, Culture, Sports, Science and Technology, Japan.

\section{References}

1. Terazono K, Yamamoto H, Takasawa S, Shiga K, Yonemura Y, Tochino $\mathrm{Y}$ and Okamoto $\mathrm{H}$ : A novel gene activated in regenerating islets. J Biol Chem 263: 2111-2114, 1988.

2. Fukui H, Franceschi F, Penland RL, Sakai T, Sepulveda AR, Fujimori T, Terano A, Chiba T and Genta RM: Effects of Helicobacter pylori infection on the link between regenerating gene expression and serum gastrin levels in Mongolian gerbils. Lab Invest 83: 1777-1786, 2003.

3. Yamagishi H, Fukui H, Sekikawa A, et al: Expression profile of REG family proteins REG Ialpha and REG IV in advanced gastric cancer: comparison with mucin phenotype and prognostic markers. Modern Pathol 22: 906-913, 2009.

4. Sekikawa A, Fukui H, Fujii S, et al: Possible role of REG Ia protein in ulcerative colitis and colitic cancer. Gut 54: 1437-1444, 2005.

5. Sekikawa A, Fukui H, Fujii S, et al: REG I $\alpha$ protein may function as a trophic and/or anti-apoptotic factor in the development of gastric cancer. Gastroenterology 128: 642-653, 2005.

6. Yonemura Y, Sakurai S, Yamamoto H, et al: REG gene expression is associated with the infiltrating growth of gastric carcinoma. Cancer 98: 1394-1400, 2003.

7. Dhar DK, Udagawa J, Ishihara S, et al: Expression of regenerating gene I in gastric adenocarcinomas: correlation with tumor differentiation status and patient survival. Cancer 100 1130-1136, 2004.
8. Sekikawa A, Fukui H, Zhang X, et al: REG I $\alpha$ is a biomarker for predicting response to chemotherapy with $\mathrm{S}-1$ plus cisplatin in patients with unresectable stage IV gastric cancer. Br J Cancer 108: 395-401, 2013.

9. Fukui H, Fujii S, Takeda J, et al: Expression of reg I alpha protein in human gastric cancers. Digestion 69: 177-184, 2004.

10. Papetti M and Herman IM: Mechanism of normal and tumor-derived angiogenesis. Am J Physiol Cell Physiol 282: C947-C970, 2002.

11. Karibe T, Fukui H, Sekikawa A, Shiratori K and Fujimori T. EXTL3 promoter methylation down-regulates EXTL3 and heparin sulphate expression in mucinous colorectal cancers. J Pathol 216: 32-42, 2008.

12. Sekikawa A, Fukui H, Fujii S, Ichikawa K, Tomita S, Imura J, Chiba $\mathrm{T}$ and Fujimori T: REG Ialpha protein mediates an anti-apoptotic effect of STAT3 signaling in gastric cancer cells. Carcinogenesis 29: 76-83, 2008.

13. Abe A, Fukui H, Fujii S, et al Involvement of cyclooxygenase-2 and vascular endothelial growth factor in vascularization and lymph node metastasis of colorectal cancers with submucosal invasion. J Gastroenterol Hepatol 22: 1071-1077, 2007.

14. Ozerdem U, Wojcik EM, Duan X, Erşahin Ç and Barkan GA: Prognostic utility of quantitative image analysis of microvascular density in prostate cancer. Pathol Int 63: 277-282, 2013.

15. Macadam RC, Sareka AI, Farmery SM, Robinson PA, Markham AF and Guillou PJ: Death form early colorectal cancer is predicted by the presence of transcripts of the REG gene family. Br J Cancer 83: 188-195, 2000.

16. Harada K, Zen Y, Kanemori Y, et al: Human REG I gene is up-regulated in intrahepatic cholangiocarcinoma and its precursor lesions. Hepatology 33: 1036-1042, 2001.

17. Zhou L, Zhang R, Wang L, et al: Upregulation of REG Ialpha accelerates tumor progression in pancreatic cancer with diabetes. Int J Cancer 127: 1795-1803, 2010.

18. Takaishi S and Wang TC: Gene expression profiling in a mouse model of Helicobacter pylori-induced gastric cancer. Cancer Sci 98: 284-293, 2007.

19. Kobayashi S, Akiyama T, Nata K, et al: Identification of a receptor for reg (regenerating gene) protein, a pancreatic beta-cell regeneration factor. J Biol Chem 275: 10723-10726, 2000.

20. Kadowaki Y, Ishihara S, Miyaoka Y, et al: Reg protein is overexpressed in gastric cancer cells, where it activates a signal transduction pathway that converges on ERK1/2 to stimulate growth. FEBS Lett 530: 59-64, 2002. 